\title{
Evaluation of healthcare networks by nurses in the Family Health Strategy*
}

\author{
Avaliação das redes de atenção à saúde pelo enfermeiro da Estratégia Saúde da Família \\ Evaluación de las redes de atención sanitaria por el \\ enfermero de la Estrategia Salud de la Familia
}

How to cite this article:

Cabral DS, Nascimento MC, Miranda TPS, Silva Júnior SI, Bittencourt F, Silva SA. Evaluation of healthcare networks by nurses in the Family Health Strategy. Rev Esc Enferm USP. 2020;54:e03589. doi: https://doi.org/10.1590/S1980-220X2018048703589

\section{Danusa da Silva Cabral ${ }^{1}$ \\ Murilo César do Nascimento ${ }^{1}$ \\ Talita Prado Simão Miranda ${ }^{2}$ \\ Sinézio Inácio da Silva Júnior ${ }^{3}$ \\ Flávio Bittencourt ${ }^{4}$ \\ Simone Albino da Silva ${ }^{1}$}

* Extracted from the dissertation: "Avaliação das redes de atenção à saúde pelo enfermeiro da estratégia saúde da família", Programa de Pós-Graduação em Enfermagem, Universidade Federal de Alfenas, 2018.

${ }^{1}$ Universidade Federal de Alfenas, Escola de Enfermagem, Alfenas, MG, Brazil.

${ }^{2}$ Universidade de São Paulo, Escola de Enfermagem de Ribeirão Preto, Ribeirão Preto, SP, Brazil.

${ }^{3}$ Universidade Federal de Alfenas, Faculdade de Ciências Farmacêuticas, Alfenas, MG, Brazil.

${ }^{4}$ Universidade Federal de Alfenas, Instituto

de Ciências Exatas, Departamento de

Estatística, Alfenas, MG, Brazil.

\begin{abstract}
Objective: To evaluate the capacity of Primary Healthcare to coordinate healthcare networks. Method: A cross-sectional, population-based and descriptive study developed in the State of Minas Gerais through interviews with nurses working in the Family Health Strategy Sector (FHS) of the Unified Health System, using the Network Coordination Assessment Tool for Primary Healthcare. A descriptive statistical analysis was applied by implementing Fisher's exact test, Spearman's correlation coefficient and cluster analysis. Type I error was fixed at 5\% for statistical significance. Results: There were 49 nurses interviewed, evaluating the population and primary healthcare dimensions as excellent. Support, logistical, governance and overall assessment systems were classified as having good condition in the network coordination for Primary Healthcare. The dendograms showed that the work process has similarities between Nurses, as well as the structure between the municipalities. Conclusion: Primary Healthcare has the ability to coordinate networks, constituting a process in which nurses have a central role. There were similarities in the work processes between evaluated municipalities and a deficit in information and pharmaceutical assistance systems.
\end{abstract}

\section{DESCRIPTORS}

Primary Care Nursing; Family Health Strategy; Family Nursing; Health Services; Program Evaluation.
Corresponding author:

Danusa da Silva Cabral

Rua Gabriel Monteiro da Silva, 700, Centro

CEP 37130-001 - Alfenas, MG, Brazil

danuscabral@yahoo.com.br
Received: 11/06/2018

Approved: 09/30/2019 


\section{INTRODUCTION}

With the institutionalization of the Unified Health System (SUS), it was necessary to implement and operationalize the public health system so that the decision-making power transfer to States and Municipalities could happen within the federative logic of each entity ${ }^{(1)}$. The next period turned to decentralizing healthcare by placing municipalities at the forefront of the system, improving access, implementing social control and qualifying the healthcare network ${ }^{(2)}$.

There was subsequently a more homogeneous structuring process of Primary Healthcare (PHC), also called Primary Care ${ }^{(3)}$, which culminated in the proposal of the Family Health Program in 1994, later understood as the Family Health Strategy (FHS), constituting a reorientation of the care model ${ }^{(4)}$. The FHS aims to organize, expand, qualify and consolidate $\mathrm{PHC}$ in Brazil in order to favor reorientation of the work process and impact the health situation of people and communities. Therefore, this is characterized as the individual's preferred gateway to the public health system ${ }^{(5)}$.

$\mathrm{PHC}$ has also become responsible for coordinating the care of individuals when they are at other levels of care, such as secondary and tertiary care ${ }^{(6)}$. Thus, the concept of Health Care Networks (HCN) initiates from this process, defined as organizations of mutual interaction, where the governance of systems is developed by a set of health services with mutual connection and directed to common purposes, aiming to offer comprehensiveness and care continuity to a defined population, being coordinated by $\mathrm{PHC}$ with a view to overcoming fragmented health care ${ }^{(7)}$.

In view of all the complexity regarding $\mathrm{HCN}$, nurses have a prominent role in $\mathrm{PHC}$ due to their general training, ease of communication with other areas, experience in planning, executing and evaluating actions ${ }^{(8)}$. They are able to supervise, organize, plan and manage health actions, favoring health promotion and disease prevention. They also perform articulation between care levels so that comprehensive care for the individual and the collective actually occurs ${ }^{(9)}$. Faced with this perspective, the question arises: how do nurses who work in the FHS evaluate the coordination of HCN through this health care point?

The advancement in reorganization of the healthcare model, the strengthening of $\mathrm{HCN}$ s, the increase in the population's access to care and its comprehensiveness can be leveraged through the production of scientific knowledge, which offers a guide for political and administrative decisions in order to qualify the healthcare within the scope of SUS. The production of scientific evidence is incipient ${ }^{(10)}$ in the specific scope of evaluative research on HCN coordination by $\mathrm{PHC}$, positioning the professional nurse as a key informant, what justifies undertaking studies such as the present.

Thus, this study aims to assess PHC's capacity to coordinate the HCN from the Nurse's perspective, identifying the involvement of this professional with their attended population, along with the coordination of the FHS and with the support, logistical and governance systems in the PHC units inserted in the HCN.

\section{METHOD}

\section{Study Design}

A cross-sectional population study of a descriptive nature.

\section{SCENARIO}

The study scenario was the health micro-region of Alfenas/Machado, located in the south of the State of Minas Gerais, and composed of 17 municipalities; one of which did not have a FHS team and the other had a single team, with only one nurse having less than six months of being employed by the FHS, thus totaling 15 municipalities participating in the study.

\section{Population}

There were 78 FHS teams identified with one nurse in each FHS, in which one sought to select professional nurses with more than six months of working time in the health unit where they were working. However, 29 of the 78 nurses were unable to participate, as 23 teams had nurses hired for less than 06 months, four teams included nurses on vacation and two did not have professional nurses working at the data collection time, thus totaling a study population of 49 nurses.

\section{Data collection}

Data collection took place from November 2017 to April 2018 , with an individual approach performed by the researcher herself in the workplace of each nurse who responded to the HCN Coordination Assessment Instrument for the PHC $(C O P A S)^{(11)}$.

The COPAS Instrument (adapted and validated in Brazil) consists of identifying and characterizing the interviewee and has 78 questions subdivided into dimensions: Population, PHC, Support Systems, Logistics System and Governance System. The following items were evaluated in the Population dimension: defined population and area, social organization of families, registered in subpopulations due to socio-sanitary risks; in the PHC dimension: link between teams and users, $\mathrm{HCN}$ communication center, PHC organization; in the Support System dimension: diagnostic and therapeutic support fields, pharmaceutical assistance, local regulations; in the Logistics System dimension: health information systems, such as electronic records, regulation system, transport; and in the Governance System dimension: organizational arrangement which enables the management of all $\mathrm{HCN}$ components ${ }^{(11)}$.

The questionnaire has a standard Likert-type response, categorized from 1 (strongly disagree) to 5 (strongly agree) (11). However, there are 18 questions which require a reversal in the response scale, namely: B2 and B12 in the population dimension; C15, C19, C22, C27 and C31 in the PHC dimension; D36, D40 and D45 in the support systems dimension; E49, E54, E59 and E62 in the logistics system dimension; and F67, F71, F74 and F78 in the governance system dimension. Thus, it is possible to standardize them so that the most positive answer is 5 and consequently the most negative is $1^{(12)}$, as determined in Chart 1 . 
Chart 1 - Scale conversion - Campinas, SP, Brazil, 2012.

\begin{tabular}{|c|c|c|c|c|c|}
\hline SCALE & $\mathbf{0} \%$ & $\mathbf{2 5} \%$ & $\mathbf{5 0} \%$ & $\mathbf{7 5} \%$ & $\mathbf{1 0 0} \%$ \\
\hline Normal & 01 & 02 & 03 & 04 & 05 \\
\hline Inverted & 05 & 04 & 03 & 02 & 01 \\
\hline
\end{tabular}

Source: Evaluation of the quality of life of HIV/AIDS patients: an overview of the WHOQOL-HIV and WHOQOL-HIV-BREF instruments ${ }^{(12)}$.

\section{DATA ANALYSIS AND PROCESSING}

The answers were organized in a database created in an electronic spreadsheet. Next, the formula in Figure $1^{(10)}$ was used, in which: Sc is the obtained score; $(\Sigma i t)$ is the sum of the items (of the grades) attributed by each researched individual; $\mathrm{N}$ is the number of individuals interviewed by municipality; $q$ is the number of items that the questionnaire has (it can vary if it is overall or an attribute); and 20 is a constant which turns the value found into a percentage. The original formula used in a pioneering study with $\mathrm{COPAS}^{(10)}$ had a constant of 200 , and it is not possible to obtain the result in percentages, but rather permilage. Therefore, the formula was adapted to the constant 20 .

$$
S c=\frac{\left(\sum i t\right)}{N x q} \times 20
$$

Figure 1 - Adapted formula ${ }^{(10)}$ for the study calculations, Alfenas, MG, Brazil, 2018.

The scores for each dimension assessed were calculated by municipality for analysis, as well as the total score of the COPAS instrument. Next, these results were classified into quartiles, adopting the performance criteria: unsatisfactory condition ( 0 to $25 \%$ ), fair ( $25.01 \%$ to $50 \%$ ), good (50.01\% to $75 \%$ ) and excellent (75.01\% to $100 \%)$, regarding the PHC's capacity to coordinate the $\mathrm{HCN}^{(10)}$.

The frequency count of the categorical variables was applied for the descriptive analysis, and the central measure calculation for the continuous variables (age and length of service in the FHS); these were later categorized considering the median.

Next, the responses of the COPAS dimensions were categorized, standardizing them according to Table 2 in order to perform the tests of associations between the independent variables of: length of service, support from the Family Health Support Center $(N A S F)$, the specialization type, the Human Development Index (HDI) of the municipality, and the population coverage of the FHS, with the dependent variable of professional evaluation.

Statistical analyzes and graphs were performed using the $\mathrm{R}$ program and a type I error was set at $5 \%$ for statistical significance. Fisher's exact test and Spearman's correlation coefficient tests were used to measure the association between the variables. The second statistical analysis consisted of a cluster analysis.

\section{ETHICAL ASPECTS}

The study was approved by the Research Ethics Committee of the Universidade Federal de Alfenas, MG, under Opinion no. 2.303.523/2017, in accordance with the recommendations of Resolution 466/2012. All participants signed the Free and Informed Consent Form.

\section{RESULTS}

Forty-nine (49) nurses participated in the study, of which $85.71 \%$ were female, with an average age of 35.71 years and working for an average of 6.12 years in the FHS. Regarding training, $16.33 \%$ of professionals had a specialization in Public Health; 34.69\% in Family Health; $20.41 \%$ in both; and $28.57 \%$ in none of these. When asked if the unit in which they worked was attended by the NASF, more than half (55.10\%) answered that it did not have this type of service.

The results of the COPAS instrument application are presented in Table 1 below.

Table 1 - Municipality performance in the $\mathrm{HCN}$ assessment dimensions - Alfenas, MG, Brazil, 2018.

\begin{tabular}{ccccccc}
\hline Municipality & B $^{*}$ & $\mathrm{C}^{*}$ & $\mathrm{D}^{*}$ & $\mathrm{E}^{*}$ & $\mathrm{~F}^{*}$ & $\mathrm{G}^{*}$ \\
\hline 1 & 82.86 & 84.21 & 75.33 & 78.75 & 75.00 & 79.49 \\
2 & 77.86 & 78.95 & 68.00 & 63.44 & 67.14 & 73.97 \\
3 & 75.71 & 67.37 & 71.33 & 60.63 & 70.00 & 68.59 \\
4 & 68.57 & 70.26 & 58.67 & 56.88 & 59.64 & 63.08 \\
5 & 78.93 & 78.95 & 61.33 & 70.42 & 68.10 & 71.97 \\
6 & 69.29 & 75.79 & 61.33 & 59.38 & 73.57 & 68.08 \\
7 & 65.71 & 70.53 & 74.67 & 55.00 & 67.14 & 66.67 \\
8 & 71.71 & 67.37 & 62.67 & 55.75 & 71.43 & 63.03 \\
9 & 71.90 & 74.39 & 65.33 & 57.92 & 64.76 & 67.09 \\
10 & 75.14 & 80.21 & 81.33 & 72.00 & 71.71 & 76.31 \\
11 & 85.71 & 79.74 & 77.00 & 66.56 & 76.07 & 76.92 \\
12 & 87.86 & 92.63 & 87.00 & 74.38 & 86.79 & 85.90 \\
13 & 74.64 & 76.58 & 75.33 & 72.50 & 72.50 & 74.42 \\
14 & 71.43 & 70.00 & 63.33 & 61.25 & 61.43 & 76.67 \\
15 & 68.93 & 71.58 & 68.00 & 55.63 & 63.57 & 77.12 \\
Mean & 75.08 & 75.90 & 70.04 & 64.03 & 69.92 & 72.62 \\
\hline
\end{tabular}

*B = Population; $\mathrm{C}=\mathrm{PHC} ; \mathrm{D}=$ Support systems; $\mathrm{E}=$ Logistics system; $\mathrm{F}=$ Governance system; $\mathrm{G}=$ Overall assessment.

The performance of the PHC capacity to coordinate the $\mathrm{HCN}$ was classified as having an excellent condition in seven municipalities for the Population dimension, eight for the PHC dimension, five for the Support Systems dimension, one for the Logistics System dimension and two for the Governance System dimension. There were no municipalities in any of the evaluated dimensions with a regular or unsatisfactory result. Moreover, six municipalities were in excellent condition for the overall assessment. Most municipalities generally obtained a good condition evaluation, except for the PHC dimension, in which the majority of the municipalities achieved an excellent evaluation.

It was considered that the PHC dimension was the best evaluated in taking the average of each dimension in a consolidating view of the micro-region, followed by the population dimension, both classified as having excellent conditions. The support systems, logistics and governance dimensions were classified as having a good condition. The 
lowest average among them was the logistics system dimension, which refers to health information systems, regulation and transport. Overall, the assessment of the HCN coordination by PHC from the perspective of nurses who work in the FHS were classified as having a good condition.
Table 2 shows the results of the association tests between the variables: Length of service in the FHS, Population coverage of the FHS, Service by NASF, Nurses' specialization and HDI of the municipality; as well as an evaluation of the professional in each dimension.

Table 2 - Distribution of data on association tests between variables - Alfenas, MG, Brazil, 2018.

\begin{tabular}{|c|c|c|c|c|c|}
\hline Association tests & Population & PHC & Support systems & Logistics system & Governance system \\
\hline Working time in the FHS & $p=0.635$ & $p=0.220$ & $p=0.253$ & $p=0.207$ & $p=0.426$ \\
\hline Population coverage & $p=0.075$ & $p=0.001$ & $p=0.012$ & $p=0.006$ & $p=0.014$ \\
\hline Service by the NASF & $p=0.770$ & $p=0.573$ & $p=0.149$ & $p=0.567$ & $p=0.158$ \\
\hline Specialization type & $p=0.578$ & $p=0.732$ & $p=0.062$ & $p=0.619$ & $p=0.956$ \\
\hline HDI & $p=0.038$ & $p=0.068$ & $p=0.251$ & $p=0.014$ & $p=0.025$ \\
\hline
\end{tabular}

In the Population dimension, the association between the HDI and the professional's assessment of this dimension increases as the municipality's HDI decreases. For the score attributed by the Nurse to the PHC dimension, there is an increase as the population coverage of the FHS grows. There was no correlation between dimension assessment and any of the variables in the Support Systems dimension.

Regarding the associations of the Logistics System dimension, as the HDI decreased, the evaluation score for this dimension increased, differently from what happens in the association of the population coverage variable of the FHS tested with the same dimension, in which there is a positive correlation. The last associations were tested with the Governance System dimension. There was a negative correlation between the dimension assessment and the HDI, and the lower the HDI, the greater the dimension assessment; furthermore, there was a positive correlation between the dimension assessment and the estimated FHS population coverage variable, in which the assessment increases as the coverage also increases.

The Cluster analysis was carried out with the objective of grouping professionals with similar profiles, identifying their work with the attended population. The professionals were named with the letter $\mathrm{M}$ in constructing the dendograms, followed by the respective ordinal number of each evaluated municipality and the letter corresponding to the alphabetical order; for example, the first professional in the first municipality was named M1a.

The COPAS overall score grouping dendrogram (Figure 2) shows that the Nurses' responses were presented in a similar manner, in groups of different municipalities than those in which they worked, without this interfering with the evaluation result.

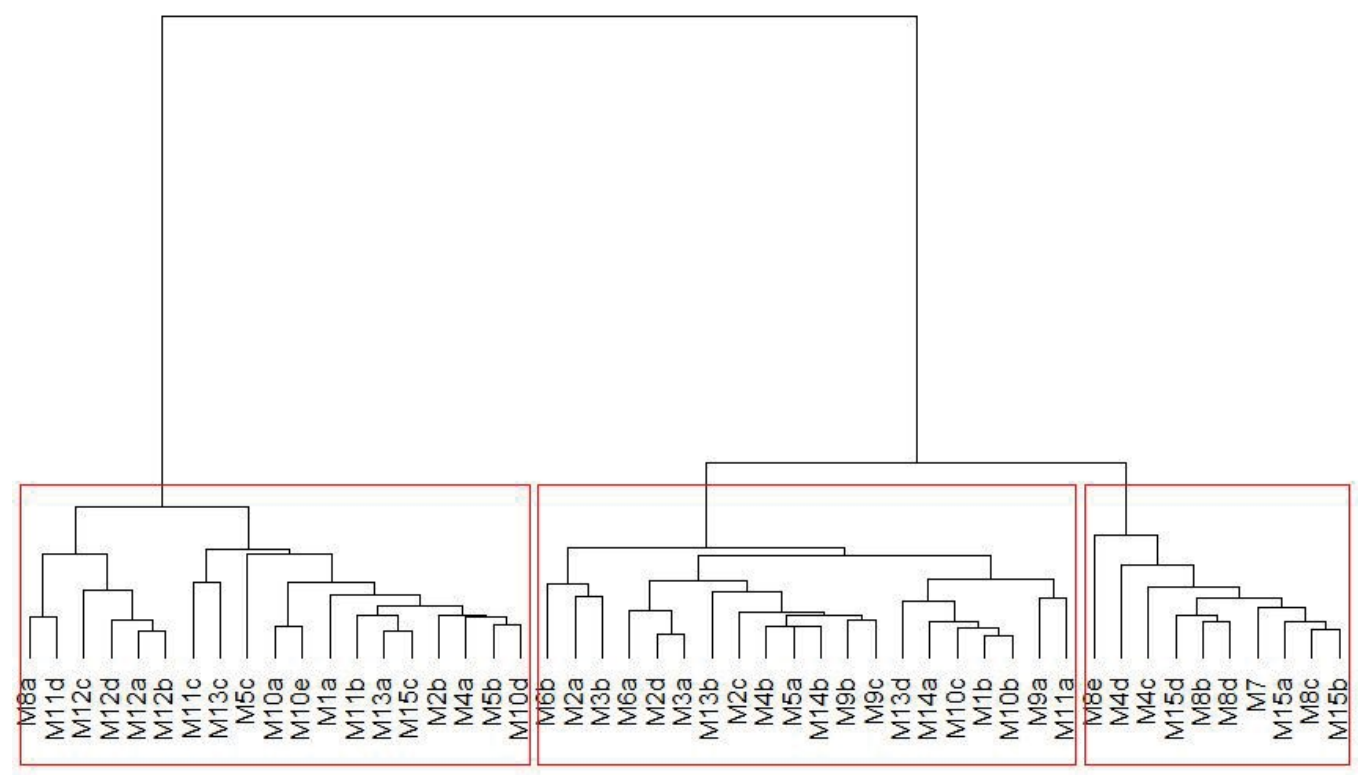

Figure 2 - Grouping of nurses according to the overall score of the COPAS instrument - Alfenas, MG, Brazil, 2018.

It was found that the nurses' evaluation of the PHC dimensions has greater similarities between professionals than between the municipalities where they work.

\section{DISCUSSION}

Regarding the profile of the nurses interviewed, there was a predominance of females, a characteristic which can be seen in other studies ${ }^{(13-14)}$ carried out in Brazilian primary care. The nurses' age was an average of 35 years old, revealing a young population, but with important professional qualification, demonstrated by professional experience, length of service in the FHS and by the presence of postgraduate studies focused on Family Health and Public Health by the majority. This can be explained by the motivation to 
specialize in Family Health as a need for improvement and professional growth in the area of choice ${ }^{(14)}$.

As a result, the study region is characterized as having great potential to develop FHS activities, as its Nurses had the technical capacity to work in Primary Healthcare with qualification and preparation for the work process within the $\mathrm{HCN}$.

Most of the population in the studied health region has access to the FHS, but without NASF support in most municipalities in the region. The lack of a support center for activities which need other professionals to monitor the population's health can result in difficulties in resolving FHS actions. With the lack of NASF support, the "consolidation of the FHS and the implementation of the comprehensive guideline are far apart based on effective matrix support" seems distant ${ }^{(15)}$.

This population is well known to the nurses, and lives in a region formed by small municipalities which have high FHS coverage and is marked by incipient development and social inequality, largely depending on public health services. When a FHS Nurse knows their territory and its population, they understand the real needs of their area, can identify health problems and have support to face the factors which can lead them into risky situations ${ }^{(16)}$.

In this context, a positive assessment sheds light on the effectiveness of current health policies. In order to combat inequities in health, social stratification mechanisms are among the most important means of reducing these inequalities, including policies which reduce differences in social conditions $^{(17)}$.

An excellent evaluation was maintained by Nurses for the $\mathrm{PHC}$ dimension. It was possible to understand the functioning of some of the constituent processes of the $\mathrm{HCN}$ and the role of the Nurse in them, especially when conducting care, as well their link to the population, in referrals to other care levels and in the communication between reference and counter-reference services/units. The FHS represents the individual, their family and the community at the PHC level, which promotes the care of their population through their actions.

The role of the Nurse is essential in the care processes. They assume the decisive role in identifying the care needs, health promotion and protection of their population in different dimensions in the $\mathrm{HCN}$. The first listening provides a link and improves communication with the user, intervenes in contact and organizes access to other care levels ${ }^{(18)}$.

The communication evaluation in the PHC dimension can be highlighted. It is essential that there is adequate communication between the care levels so that referrals can be carried out and users can return to the FHS with the necessary clinical information for care continuity.

It is understood that when the nurse is working in a municipal health system that has adopted the FHS as a priority in the organization of primary care services, the perception of the professional becomes more positive about the role of this level of care in the HCN. The national expansion of FHS coverage in recent years has contributed to this, offering more care provision to a larger number of inhabitants ${ }^{(14)}$.
"The increase in the coverage and scope of family health is an important promoter of equity and the SUS has fulfilled its mission, making the FHS effective as a healthcare provider"(19). The expressive expansion of FHS coverage and the fact that municipalities can count on complete FHS provided significant effects on health indicators, both for those which signal an increase in the supply of services and for those that refer to health outcomes, demanding progressive structuring and qualification of the diagnostic and therapeutic support network ${ }^{(20)}$.

Support Systems was the third dimension evaluated, which mostly had a good rating. Despite this, an unsatisfactory evaluation appears in the evaluation items that refer to the PHC pharmacy. This result is conditioned by the inexistence of such a structure in many of the units, the reduced availability of drugs in those which do exist, and the diminished role/position of the pharmaceutical professional with the work of the FHS team. Nurses were unaware of the processes which were carried out in many of the units that had pharmacies, such as which forms are used, medication distribution control, educational material for the population, among others. Multiprofessional work in PHC requires the presence of the pharmacist in making therapeutic decisions to improve the care process, and avoiding harm to the population's health ${ }^{(21)}$.

The unsatisfactory evaluation also extended to imaging exams. These are scheduled for other locations, and there is a longer delay in scheduling and running the exam. This finding is conditioned by the small size of the municipalities, which use diagnostic imaging services in the main cities of the micro region due to the regionalized context. At the same time that there is a defined flow, communication between network points is not effective due to the difficulties already listed.

The Support Systems are a constituent part of the operational structure of the $\mathrm{HCN}$ and correspond to one of the "nodes" which make up the networks, and whose communicating center is the PHC; the flows and counter flows of the healthcare system are coordinated in these systems ${ }^{(7)}$. Thus, this dimension needs to be added to the other HCN systems, so that the PHC meets the existing challenges, mainly in the fragility of implementing an integrated network between the care levels, thereby supporting the communication flows and the processes for social health production ${ }^{(22)}$.

The Support Systems dimension was the only one which did not correlate with any variable in the association tests. This means that even though a homogeneous integration of these systems with PHC was revealed, it was low.

Regarding the Logistics System dimension evaluation, the results were quite evident in relation to the absence of information systems in PHC, especially the electronic medical record. Only one municipality had the medical record implanted at the time of data collection; this was precisely the only one to be classified as having an excellent condition, with all the others being in good condition. The importance of an information system which integrates the $\mathrm{HCN}$ services with the PHC services is undeniable, thus promoting user monitoring at each care point. The Nurse, as well as the other 
professionals of the team, will only be able to coordinate care of their population if they have all the necessary information.

The absence of computerized and integrated medical records minimizes the possibilities of communication between professionals, making it difficult to coordinate care in $\mathrm{PHC}^{(23)}$. Therefore, the need to invest in inputs and equipment to improve PHC performance and quality is ratified ${ }^{(24)}$.

The first correlation presented in the Logistics System assessment was with the HDI of the municipalities, in which the evaluation of the dimension increased according to a decrease in this index. Another correlation found was the evaluation of the Logistics System dimension with the FHS coverage. In this case, as coverage increased, the assessment also had a higher score. This demands that the municipal Logistics System be more organized in order to reduce costs and optimize service to the population.

The results of the last evaluated dimension showed that the municipalities also had a good classification regarding the Governance System. This fact shows that Nurses see an appreciation of the PHC level within the municipal management system. Municipal health secretaries are active actors in this organization, offering subsidies for popular and health workers' participation.

Regarding the existence of some PHC assessment and monitoring system, unsatisfactory responses indicate that there are no municipalities in the micro-region capable of having their own system for this purpose, anchoring themselves in the already pre-established systems at the state and federal levels. It is understood that this evaluation is only promoted at the federal level by the Ministry of Health, through the National Program for Improving Access and Quality in Primary Care $(P M A Q-A B)$. The PMAQ-AB seeks to evaluate and promote interventions through qualifying Primary Healthcare teams in their institutional capacity, promoting changes in service practices and expanding the impact on the health conditions of the population, with a focus on the user ${ }^{(25)}$.

It is noteworthy that all associations made between the variables length of time working in the FHS, specialization type and whether there is support from the NASF with the five evaluated dimensions did not show any correlation. This confirms that the health region under study has competent Nurses for functioning and knowledge of $\mathrm{PHC}$ activities in coordinating the $\mathrm{HCN}$, producing benefits for the attended population.

The characteristic presented in the dendrogram, in which the nurses' responses were not grouped according to their municipality, enables inferring that the structure of the municipalities at the PHC level which link them to the $\mathrm{HCN}$ is seen and accessed differently by Nurses.

Finally, the result of the overall assessment of the HCN coordination by $\mathrm{PHC}$ obtained a satisfactory result, in which no municipality was classified as having an unsatisfactory or regular condition. This translates into recognizing PHC as the preferred gateway to health services and as the coordinating center for the HCN; the FHS Nurse has a fundamental role in guiding users at different care levels.

The present study is limited because it was carried out in a micro-region composed of small municipalities with characteristics which do not allow to generalize the results. That said, it is reflected that nurses from other cities and other regions of the country, with different social, economic and organizational realities, may have different interpretations about the scope of this evaluation, which will culminate in other results.

\section{CONCLUSION}

Evaluation studies of the $\mathrm{HCN}$ are extremely important for the SUS, since the legislation which regulates these networks is relatively new and little has been produced about their functioning. In their assessment, the Nurses confirmed that PHC is a preferred gateway for the population, especially given its high population coverage in a region whose social structure (denoted by the HDI) needs this powerful care level in order to achieve equity of access, and to improve the quality of life. However, the dimensions which evaluate the processes, and which go beyond the performance of the FHS team itself, showed weaknesses which can compromise achieving comprehensiveness and coordinating care at the first level of care. Thus, it is considered that the region needs to qualify healthcare in the networks, especially in the dimensions which refer to pharmaceutical assistance and the information system, as the latter has a great impact on the quantity and quality of information necessary for care continuity through reference and counter-reference services.

This study enabled adding scientific knowledge in the health services management area, a strategic area of the SUS, and a broad field of action for nurses. It provided contributions so that other researchers can have scientific interest and generate new research from the information presented herein, as well as using the COPAS Instrument which provides important information for constructing an organized and hierarchical network.

\section{RESUMO}

Objetivo: Avaliar a capacidade da Atenção Primária à Saúde de coordenar as Redes de Atenção à Saúde. Método: Estudo transversal, populacional, de natureza descritiva, desenvolvido no Estado de Minas Gerais por meio de entrevista com enfermeiros que atuam na Estratégia de Saúde da Família, utilizando o Instrumento de Avaliação da Coordenação das Redes pela Atenção Primária. Aplicou-se análise estatística descritiva; Teste Exato de Fisher, Coeficiente de correlação de Spearman e análise de agrupamento de Cluster. Fixouse erro tipo I em 5\% como estatisticamente significativo. Resultados: Entrevistaram-se 49 enfermeiros, que avaliaram as dimensões população e atenção primária à saúde como ótimas. Sistemas de apoio, logístico, governança e a avaliação global foram classificados como tendo condição boa na coordenação das redes pela Atenção Primária. Os dendogramas mostraram que o processo de trabalho apresenta semelhanças entre os Enfermeiros, assim como a estrutura entre os municípios. Conclusão: A Atenção Primária possui capacidade de coordenar as redes, processo no qual o Enfermeiro tem papel de centralidade. Houve semelhanças no processo de trabalho entre municípios avaliados e um déficit nos sistemas de informação e assistência farmacêutica.

\section{DESCRITORES}

Enfermagem de Atenção Primária; Estratégia Saúde da Família; Enfermagem Familiar; Serviços de Saúde; Avaliação de Programas e Projetos de Saúde. 


\section{RESUMEN}

Objetivo: Evaluar la capacidad de la Atención Primaria en Salud de coordinar las Redes de Atención Sanitaria. Método: Estudio transversal, poblacional, de naturaleza descriptiva, desarrollado en el Estado de Minas Gerais mediante entrevista con enfermeros que actúan en la Estrategia de Salud de la Familia, utilizando el Instrumento de Evaluación de la coordinación de las Redes por la Atención Primaria. Se aplicó el análisis estadístico descriptivo, la prueba Exacta de Fisher, el Coeficiente de correlación de Spearman y el análisis de conglomerados (Cluster). Se fijó error tipo I en el 5\% como estadísticamente significativo. Resultados: Se entrevistaron 49 enfermeros, quienes evaluaron las dimensiones población y atención primaria en salud como excelentes. Sistemas de apoyo logístico, gobernanza y evaluación global fueron clasificados como teniendo condición buena en la coordinación de las redes por la Atención Primaria. Los dendogramas mostraron que el proceso laboral presenta semejanzas entre los Enfermeros, así como la estructura entre los municipios. Conclusión: La Atención Primaria tiene capacidad de coordinar las redes, proceso en el que el Enfermero juega un rol de centralidad. Hubo similitudes en el proceso laboral entre los municipios evaluados y un déficit en los sistemas de información y asistencia farmacéutica.

\section{DESCRIPTORES}

Enfermería de Atención Primaria; Estrategia de Salud Familiar; Enfermería de la Familia; Servicios de Salud; Evaluación de Programas y Proyectos de Salud.

\section{REFERENCES}

1. Cunha EN, Souza MKB. A regionalização da saúde enquanto princípio organizativo para a gestão do SUS. Rev Enferm UFPE [Internet]. 2017 [citado 2017 maio 15]; 11(5):2145-56. Disponível em: http://periodicos.ufpe.br/revistas/revistaenfermagem/article/view/23370/19003

2. Reis AAC, Sóter APM, Furtado LAC, Pereira SSS. Thoughts on the development of active regional public health systems. Ciênc Saúde Coletiva [Internet]. 2017 [cited 2018 set. 04];22(4):1045 Available from: http://www.scielo.br/scielo.php?script=sci_arttext\&pid=S1413$81232017002401045 \& \operatorname{lng}=$ pt\&nrm=iso\&tlng=en

3. Cecilio LCO, Andreazza R, Carapinheiro G, Araújo EC, Oliveira LA, Andrade MGG, et al. A atenção básica à saúde e a construção das redes temáticas de saúde: qual pode ser o seu papel? Ciênc Saúde Coletiva 2012;17(11):2893-902. DOI: http://dx.doi.org/10.1590/S141381232012001100006

4. Lavras C. Atenção primária à saúde e a organização de redes regionais de atenção à saúde no Brasil. Saúde Soc [Internet]. 2011 [citado 2017 dez. 13];20(4):867-74. Disponível em: http://www.scielo.br/scielo.php?script=sci_arttext\&pid=S0104-12902011000400005

5. Brasil. Ministério da Saúde. Portaria n. 2.436, de 21 de setembro de 2017. Aprova a Política Nacional de Atenção Básica, estabelecendo a revisão de diretrizes para a organização da Atenção Básica, no âmbito do Sistema Único de Saúde (SUS) [Internet]. Brasília; 2017 [citado 2017 dez. 13]. Disponível em: http://bvsms.saude.gov.br/bvs/saudelegis/gm/2017/prt2436_22_09_2017.html

6. Lapão LV, Arcêncio RA, Popolin MP, Rodrigues LBB. The role of Primary Healthcare in the coordination of Health Care Networks in Rio de Janeiro, Brazil, and Lisbon region, Portugal. Ciênc Saúde Coletiva [Internet]. 2017 [cited 2018 Oct 04];22(3):713-24. Available from: http://www.scielo.br/scielo.php?script=sci_arttext\&pid=S1413-81232017002300713\&lng=pt\&nrm=iso\&tlng=en

7. Mendes EV. As redes de atenção à saúde. Ciênc Saúde Coletiva [Internet]. 2010 [citado 2017 jun. 04];15(5):2297-305. Disponível em: http://www.scielo.br/scielo.php?script=sci_arttext\&pid=S1413-81232010000500005\&lng=en

8. Moll MF, Goulart, MB, Caprio AP, Ventura CAA, Ogoshis AACM. O conhecimento dos enfermeiros sobre as Redes de Atenção à Saúde. Rev Enferm UFPE [internet]. 2017 [citado 2018 abr. 11];11(1):86-93. Disponível em: https://periodicos.ufpe.br/revistas/revistaenfermagem/ article/viewFile/11881/14338

9. Freitas GM, Santos NSS. Atuação do enfermeiro na Atenção Básica de Saúde: revisão integrativa de literatura. Rev Enferm Cent Oeste Min. 2014;4(2):1194-203. DOI: http://dx.doi.org/10.19175/recom.v0i0.443

10. Popolin MP, Touso MM, Yamamura M, Rodrigues LBB, Garcia MCC, Arroyo LH, et al. Integrated health service delivery networks and tuberculosis avoidable hospitalizations: is there a relation between them in Brazil? BMC. 2016;16(78):1-11. DOI: https://doi.org/10.1186/ s12913-016-1320-y

11. Rodrigues LBB, Leite, AC, Yamamura M, Deon KC, Arcêncio RA. Coordenação das redes de atenção à saúde pela atenção primária: validação semântica de um instrumento adaptado. Cad Saúde Pública [Internet]. 2014[citado 2017 mar. 24];30(7):1385-90. Disponível em: http://www.scielo.br/scielo.php?script=sci_arttext\&pid=S0102-311X2014000701385\&lng=pt

12. Pedroso B, Gutierrez GL, Duarte E, Pilatti LA, Picinin CT. Da qualidade de vida de portadores de HIV/AIDS: uma visão geral dos instrumentos WHOQOL-HIV e WHOQOL-HIV-BREF. Rev Facul Educ Física UNICAMP. 2012;10(1):50-69. DOI: https://doi.org/10.20396/ conex.v10i1.8637688

13. Souza ASJ, Marques MA, Moreira TMM, Araújo ADIR, Silva AZ, Machado ALG. Nursing consultation to hypertensive patients in family health strategy. Rev Enferm UERJ. 2015;23(1):102-7. DOI: http://dx.doi.org/10.12957/reuerj.2015.15597

14. Faria MGA, Acioli S, Gallasch CH. Perfil de enfermeiros fluminenses da Estratégia de Saúde da Família participantes de um curso de especialização. Enferm Foco. 2016;7(1):52-5. DOI: https://doi.org/10.21675/2357-707X.2016.v7.n1.667

15. Silva ICB, Silva LAB, Lima RSA, Rodrigues JA, Valença AMG, Sampaio J. Processo de trabalho entre a Equipe de Atenção Básica e o Núcleo de Apoio à Saúde da Família. Rev Bras Med Fam Comun. 2017;12(39):1-10. DOI: https://doi.org/10.5712/rbmfc12(39)1433

16. Almeida JHH, Feitosa ANA, Araújo WA, Silva JB, Lourenço LC, Souza MNA. Primary health care: focusing on the health for the attention of networks. Rev Enferm UFPE [Internet]. 2015 [cited 2018 Jul 24];9(11):9811-6. Available from: https://periodicos.ufpe.br/revistas/ revistaenfermagem/article/view/10772

17. Molin S, Mendes HJ, Xavier A, Pinto ECH, Bastos JRM, Velasco SEM, et al. Equidade na Estratágia Saúde da Família (ESF). Rev Bras Promoção Saúde. 2015;28(1):113-8. DOI: http://dx.doi.org/10.5020/18061230.2015.p113

18. Silva SS, Assis MMA. Family health nursing care: weaknesses and strengths in the Unified Health System. Rev Esc Enferm USP. 2015;49(4):603-9. DOI: http://dx.doi.org/10.1590/S0080-623420150000400010 
19. Malta DC, Santos MAS, Stopa SR, Vieira JEB, Melo EA, Reis AAC. Family Health Strategy Coverage in Brazil, according to the National Health Survey, 2013. Ciênc Saúde Coletiva [Internet]. 2016 [cited 2018 Oct 23];21(2):327-38. Available from: http://www.scielo.br/pdf/ csc/v21n2/en_1413-8123-csc-21-02-0327.pdf

20. Pinto HA, Sales MJT, Oliveira FP, Brizolara R, Figueiredo AM, Jerzey S. O Programa Mais Médicos e o fortalecimento da Atenção Básica. Divulg Saúde Debate. 2014;(51):105-20.

21. Pereira NC, Luiza VL, Cruz MM. Serviços farmacêuticos na atenção primária no município do Rio de Janeiro: um estudo de avaliabilidade. Saúde Debate [Internet]. 2015 [citado 2018 out. 16]; 39(105):451-68. Disponível em: http://www.scielo.br/scielo.php?pid=S0103$11042015000200451 \&$ script=sci_abstract\&tlng=pt

22. Rodrigues LBB, Silva PCS, Peruhype RC, Palha PF, Popolin MP, Crispim JA, et al. A atenção primária à saúde na coordenação das redes de atenção: uma revisão integrativa. Ciênc Saúde Coletiva [Internet]. 2014 [citado 2017 ago. 25];19(2):343-52. Disponível em: http:// www.scielo.br/scielo.php?script=sci_arttext\&pid=S1413-81232014000200343\&lng=en

23. Bousquat A, Giovanella L, Campo SEM, Almeida PF, Martins CL, Mota PHS, et al. Primary health care and the coordination of care in health regions: managers' and users' perspective. Ciênc Saúde Coletiva [Internet]. 2017 [cited 2018 Sep 16];22(4):1141-54. Available from: http://www.scielo.br/scielo.php?script=sci_arttext\&pid=S1413-81232017002401141\&lng=en

24. Turci MA, Lima-Costa MF, Macinko J. Influência de fatores estruturais e organizacionais no desempenho da atenção primária à saúde em Belo Horizonte, Minas Gerais, Brasil, na avaliação de gestores e enfermeiros. Cad Saúde Pública [Internet]. 2015 [citado 2017 ago. 24]; 31(9):1941-52. Disponível em: http://www.scielo.br/scielo.php?script=sci_arttext\&pid=S0102-311X2015000901941\&lng=en

25. Chaves LA, Jorge AO, Cherchiglia ML, Reis IA, Santos MAC, Santos AF, et al. Integração da atenção básica à rede assistencial: análise de componentes da avaliação externa do PMAQ-AB. Cad Saúde Pública [Internet]. 2018 [citado 2018 set. 15];34(2):1-16. Disponível em: http://www.scielo.br/scielo.php?script=sci_arttext\&pid=S0102-311X2018000205004\&lng=en 